IRSTI 06.71 .03

UDC 334.012

https://doi.org/10.46914/1562-2959-2020-1-4-188-194

B.M. BAYADILOVA, ${ }^{1}$

PhD student.

A.A. AMANBAYEVA, ${ }^{1}$

$\mathrm{PhD}$, senior lecturer.

A.S. KOICHUBAYEV, ${ }^{2}$

$\mathrm{PhD}$, acting associate professor.

Kazakh Humanitarian Law Innovative University. ${ }^{1}$

Shakarim State University of Semey ${ }^{2}$

\title{
FOREIGN EXPERIENCE IN THE FORMATION OF AN INNOVATIVE ENVIRONMENT FOR THE DEVELOPMENT OF SMALL AND MEDIUM SIZED ENTERPRISES
}

\begin{abstract}
The article examines the efficiency of various international expertise in adopting the innovative environment among small and medium-sized enterprises sector and creating similar innovative potential in Kazakhstan. SMEs sector is considered a vital part of any single economy of the world, there a lot of explanations on this situation, such as an increase of job opportunities and rise of GDP; therefore there is a huge number of different practices implemented in order to increase the efficiency and benefits of this market. In addition, this research describes not only possible measures to improve the business environment for small and medium-sized enterprises (SMEs) in general, but also concrete measures aimed at directly stimulating SMEs. While some developed countries introduced the newest innovative financial platforms such as getting SMEs in IPO, developing countries can still use the opportunities to fight against poverty in cooperation with international organizations that provide world-class training for SMEs. Additionally, the significance of a digitalization of operational processes of SMEs is emphasized. Although different practices can make a significant contribution on their own, it is argued that the policies of creating an innovative environment should be multi-sided, involving different activities implemented simultaneously, not only focusing on governmental support, but also innovating new independent projects with the help of the government. The conclusions received in this research provides the basis for the adoption of these methods and practices in the development of small and medium-sized businesses in the Republic of Kazakhstan and Central Asian countries.
\end{abstract}

Key words: business support, international projects, digitalization, business diversification, innovation potential, small and medium-sized businesses, efficiency.

Small and medium-sized enterprises (hereinafter referred to as SMEs) are the predominant figures in every single economy of the world, performance of which act as the main demonstrator of the economic situation of the country as a whole. There is no unified definition of SMEs, yet for the sake of simplicity, this paper will determine the small enterprises as businesses that consist of 10-100 employees, and medium enterprises as ones ranging from 100-250 laborers. The impact of SMEs on the economic indicators of the countries is undoubted. The recent report of OECD [3, p. 6] reveals that they are the irreplaceable form of businesses, accounting for approximately $99 \%$ of all firms, $70 \%$ of all jobs, and $50 \%$ and $60 \%$ of value-added on average in OECD area. The same trend can be observed in emerging markets, where SMEs constitute about $45 \%$ of total employment and $33 \%$ of GDP. The mentioned numbers can act as the underlying justification of the idea that the support of the development of SMEs is one of the primary focuses of all markets.

Even though the SME sector is becoming one of the fast-growing economies in most parts of the world, the trend is not the same for all states. Take for example Kazakhstan, which, despite the fact of availability of government support through financial grants and favorable infrastructure based on specialized quasi-sovereign organizations, still has its SMEs contributing only to 25\% of GDP and $30 \%$ of total employment in comparison with OECD countries [3, p. 46]. The progress of latter states that can be viewed at present times, however, could not be achieved without government inputs and innovative strategies. Therefore, the paper's primary focus is to analyze the experience of different states in the creation of an innovative environment and potential for their SMEs to show how multisided attempts can lead to the fostering of the economic growth of the markets generally. The paper's 
purpose is to demonstrate how the experience of countries with different economic situations can contribute to the policy-making of the development of SMEs.

The paper is divided into two segregated parts, analyzing strategies prevailing for the developed countries, such as Germany or Canada in the first one. The second part is focused primarily on developing countries and their cooperative sources to improve the business environment. The work finally concludes that to achieve the highest level of innovative potential in SMEs sector, multi-sided attempts should be implemented where multiple policies will act simultaneously.

Lessons from developed countries. The following section will evaluate the experience of developed countries, such as Canada, China, and Germany, in the creation of an innovative environment and fostering innovative potential for their SMEs through providing the easier and more profitable access to financing and appropriate educational campaign to increase the business spirit among their citizens.

According to the data presented in Asian Development Bank's [7] thematic evaluation, both small and medium-sized businesses regard access to finance as the second most important obstacle, after the informal sector, in their performance. This problem was mainly fostered by the lack of suitable collateral from the owners of those start-up projects or limited trust of banks in their ability to repay. As the reflection of this problem, the very new term named Multilateral Trading Facility (hereinafter referred to as MTF) was introduced in many of the leading exchanges of the world.

MTF is the self-regulated financial platform, that is considered as the alternative of the stock exchange for small and medium organizations. Until this platform provides the SMEs with an easier way of finding future investors and increases the liquidity of their shares, the MTF can be valued as the unique innovative alternative financial instrument that is already practiced in such places as Canada, China or Europe.

One of the compelling examples that show how Europe excelled in providing their SMEs with this financial platform is the Nasdaq First North, the branch of the Nasdaq stock exchange, which is primarily focused on creating the growth platform for international entrepreneurs. Functioning for more than three years, Nasdaq First North has now more than 300 companies trading their shares and a modern ecosystem with advisors ensuring the smooth listing process and wide investor base [8]. The same trading platform was also established in Shenzhen Stock Exchange in China, called SME Board, which has been successfully operating for 15 years. According to the official web-platform of Shenzhen Stock exchange [5], as of May 27, 2019, the 933 listed companies on the SME Board had a total IPO financing of CNY612.7 billion, and a total refinancing of CNY1.6 trillion, indicating the increasingly enhanced direct financing function. The listed SMEs were freely able to find the investors through IPO-based financial structure and provided with an innovative and competitive environment which eased the listing processes and required less documental work.

As it can be noticed from the Figure 1 below [8], the number of IPOs issued by SME Board of Shenzhen Stock Exchange easily competes with the Mainboard of New York and Honk Kong stock exchanges.

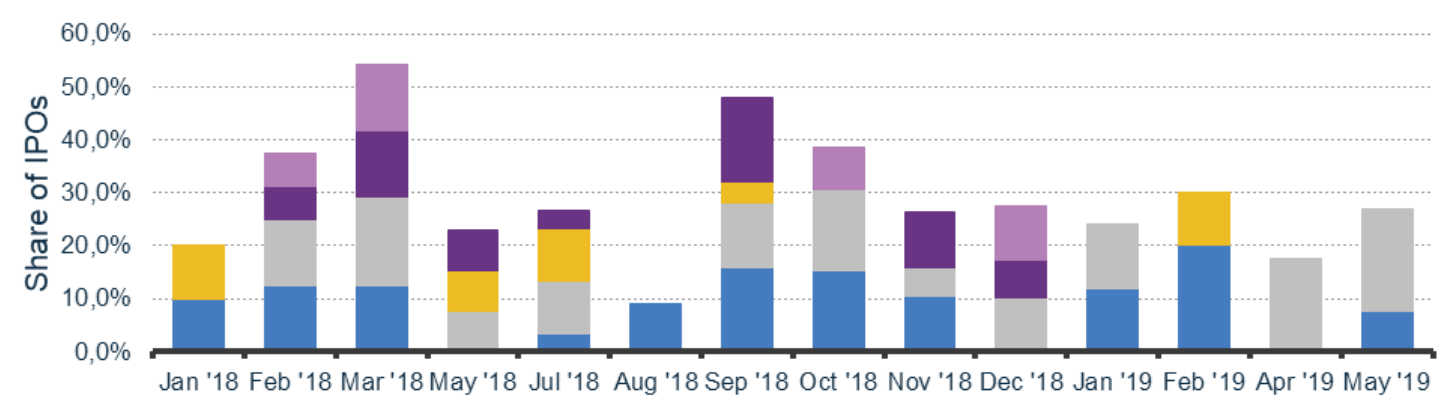

- Shenzhen Stock Exchange SME Board $\quad$ NASDAQ Stock Exchange

- Hong Kong Exchange GEM

- New York Stock Exchange = Others

Figure 1 - Distribution of Chinese IPOs based on number of IPOs, \% [8] 
After evaluating the positive outcomes of MTF in Asia and Europe, the compelling example of the success of North American states of implementing this platform would also benefit the argument. Similar to SME Board and Nasdaq First North, the Toronto Stock exchange also created a very new branch named Toronto Stock Venture Exchange, the venture capital marketplace, which is specifically focused on getting small and medium-sized companies to IPOs and sell their shares at the same level as large corporations. Taking into account that this new financial platform is persistent also in those leading economies as Luxembourg, London, New York, Tokyo, and Hong Kong, the benefits of having SMEs getting IPO-ed is undoubted and justifiably advised for all emerging markets which would like to increase the value this sector brings to the economy as a whole.

Case Study - How Germany became the country with the most developed SMEs?

Germany can be considered as a role model of providing its SME sector with the up-to-date innovations and full government support. This country can act as an example for all emerging countries in the world of how multi-sided attempts are helpful of accomplishing one goal. The reasons of success of Germany can be considered from several perspective. In this paper, the arguments presented in the case study «The Role of Small and Medium-Sized Enterprises in Development» will be used to demonstrate which factors influenced the development of SME sector the most [4].

The study reveals that $99.6 \%$ of all firms in Germany are from SMEs sector, which created almost $60 \%$ of total employment within the state. The core reasons for this positive outcome can be divided into 4 categories:

1. Access to finance - unlike such places as US or UK, Germany loaning system is non-profit oriented. Neither public saving banks nor cooperative banks, which account for $29.4 \%$ and $11.8 \%$ in the total German Bank asset are profit-oriented. The mentioned banks are mandatory to support the local economy, being permitted to assign loans only within specified geographical region. The risk of financial loss is also smoothly shared, as in the case of failing to repay, the responsibility is shared with whole system. So, the financing system is relied on the relationship lending, usually having a long credit history between bank and firms [4, p. 9].

2. Education system - the German educations system included vocational education and training system as a mandatory. The benefit of the education system to SME sectors is that there will be less labor turnover and more skilled professionals that will contribute to the emerging companies $[4, \mathrm{p}$. $10]$.

3. Industrial clusters and value chains - Industrial clusters in Germany bring together the businesses from all sectors, and foster the trade and, consequently, the economic development of the whole sector. German SMEs also contribute to the exports of their country substantially [4, p. 15].

4. Social market economy - compared to developing countries, the level of income inequality in Germany is considerably low and regulatory and legal framework is established in the manner that favors the businesses the most. The state has powerful employer's associations and federations, which play an important role for SMEs. They organize the knowledge exchange programs and establish cooperation between firms, which creates the friendly and healthy working environment in the business sector [4, p. 18].

The literature review for this study demonstrated that of government constructs the policies in SMEs development in accordance with the vision of the owners of companies and general public, the strong chain of interrelated strategies can be implemented which will inevitably result in success as Germany has.

Is the Digitalization the new requirement for SMEs?

Meeting the demand of today's requirements, the SME sector is inevitably influenced by the world's tendency to digitalize all of its spheres. The developed countries, the European ones, in this case, have been demonstrating an excellent result by providing their citizens with special centers that can assist any owner in the way of digitalizing their operations. The Report by Federal Ministry of Economic Affairs of Germany «SMEs Digital», gives insight on how the support of Digital Competence Centers create new opportunities for SMEs. Besides, it is also worth to mention here that the same kind of specific organization is available not only in Germany but in the world arena. The project Digitalise SME [1], funded by the EU, is created to support SMEs in the whole European territory by providing online consulting and advisory work. They also offer the chance of participating in a real case study 
by providing with a 1-month fully-paid internship in real corporations, so they can then implement the acquired knowledge in their businesses.

To illustrate the idea, the Figure 2 below shows the results of survey regarding the growth rate of SME in Finland due to digitalization [1], as it can be analyzed, the companies tend to agree with the idea that the more digitalized they become, the higher their potential growth is. Moreover, the tendency of exponential growth is present, implying the higher the growth rate of a company is, more significant role digitalization takes.

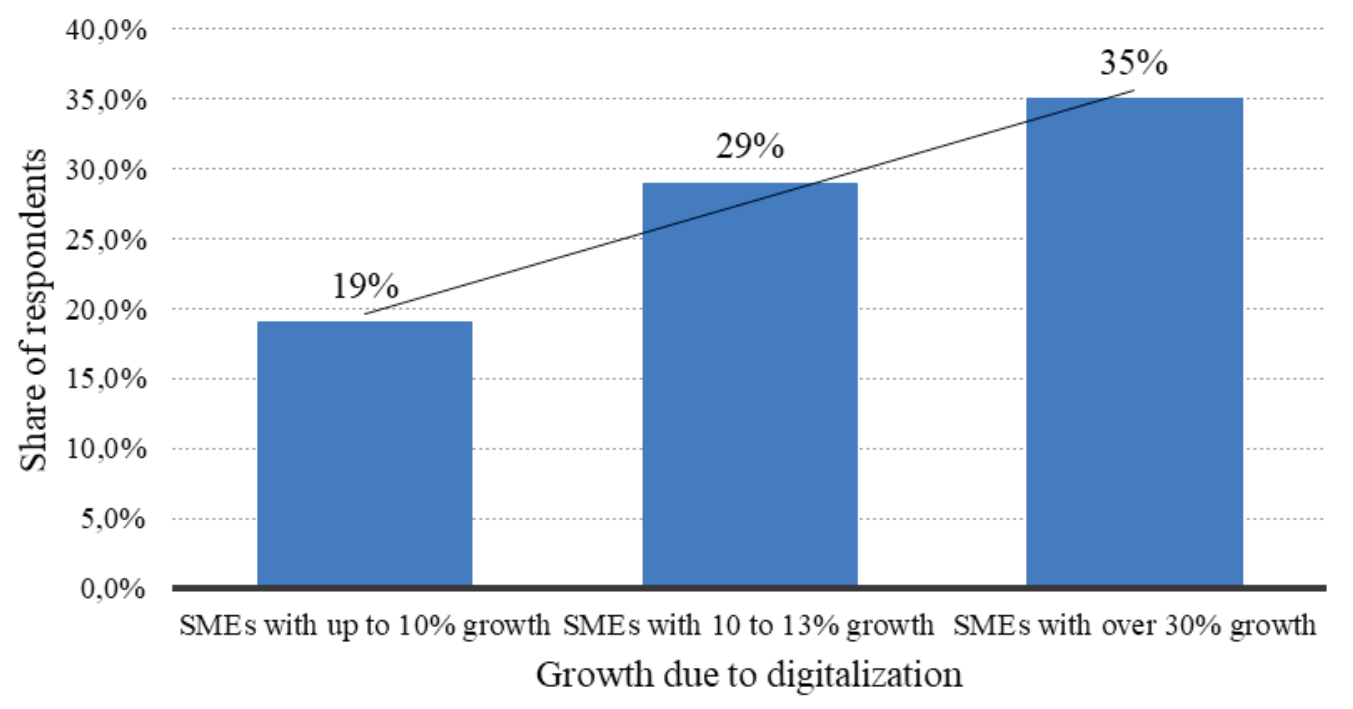

Figure 2 - What percentage of your company's last year's growth is due to digitalization? [1]

Even though digitalization contributes to the transparency in work processes and significantly lessens the workload for enterprises, this type of innovation is usually persistent in developed countries comparing to developing ones. However, it should be always kept in mind that policies successfully working in European territory, if adapted properly, can also act positively in the developing countries, such as India, Mongolia or Kazakhstan. Therefore, digitalization is considered as an effective tool in increasing public awareness and efficiency.

Lessons from developing countries. This section of the paper is to highlight the importance and efficiency of the collective and collaborative approach to create an innovative environment in developing countries. Various international organizations are specialized in providing the best practices to the regions of the Third World, and this section will mention two of them: the United Nations Industrial Development Organization (UNIDO) and the International Labor Office.

One cannot argue that the small and medium businesses create major job opportunities for the public, therefore they are especially important in developing the economy of developing countries. However, the common problem that is persistent among SMEs in developing countries is the lack of regulatory and legal framework and technological lagging. UNIDO [7], in turn, is dedicated to offering special programs to fight against poverty in low-income areas by focusing on fostering the development of the SMEs and provide them with the newest innovations. If to look at the official website of UNIDO, it is stated that the main areas of focus are automotive supplier development, business partnership, creation of clusters and network development along with export promotion. The given programs are highly promising to ensure that SMEs in poor countries are being offered opportunities to develop and surrounded by a favorable working environment. The technical report by Natascha Weisert, the Industrial Development Officer at UNIDO [7], states that a cluster development only has already been launched in such countries as Ecuador, Montenegro, Nicaragua, Russia, Turkey, Ethiopia, Senegal, and South Africa. With the help of such organizations, countries, regardless of 
their economic situation, can be granted with the support in implementing world innovations and technological advances, which ensure the promising future for the poor countries' business sector.

If the UNIDO program has been closely cooperating with most of the African countries, the SCORE program by International Labor Office, abbreviated from Sustain Competitive and Reasonable Enterprises covers most of the Asian and Pacific states, such as China, Myanmar, India, Vietnam, and Indonesia. The program aims to increase the productivity and working conditions of laborers in local SMEs by offering training in in-factory consulting and organizational structures. Currently, more than 300,000 employees benefitted from the training programs and over 1400 companies went through educational programs. [2, p. 2]. The working conditions improved significantly as well, as there was a $25 \%$ decrease in the number of accidents and a 35\% decrease in waste between 2010-2017 in the SMEs that took the training. One more striking figure is that the cost-saving soared by $65 \%$ in the given period, demonstrating that workers were given the newest innovative strategies to increase the cost-efficiency [2, p. 6].

Although there is a common stereotype that developing countries' business sector suffers from being undeveloped, there is no reason to say that the low-income states do not use the opportunities offered by world organizations and provide their SMEs with an innovative environment for future progress.

Given the above analysis of foreign countries and their expertise, it can be assumed that there is no unique single approach, innovative environment is created by a complex system that consists of a chain of steps, acting simultaneously. It is worth mentioning whether Kazakhstani suits this criteria. Indeed, the country makes attempts to strive innovative potential of SMEs by establishing the "Damu" project, whose main aim is to stimulate development of entrepreneurship. However, analyzing its official convention, there is a number of strict requirements to receive some assistance from the project, regardless whether it is business education (which is not mandatory) or credits. Moreover, most of the procedures are still not digitalized properly. On the other side, Astana International Exchange (AIX) was established in a form of trade platform benchmarked from the Shanghai Stock Exchange [6]. Unfortunately, these efforts do not cooperate with each other which is manifested by the absence of MTF, even though a branch from AIX could be created. Thus, the projects have absolutely different focus of their functioning, even though their aims are correlated.

It can be said that Kazakhstan is working towards innovative environment, but less efficiently due to lack of simultaneous efforts and cooperation.

The paper demonstrated some well-known practices used by developed and developing countries and revealed their undoubted results brought to the economies of those places. However, some limitations of this paper should also be mentioned. Firstly, due to scope and constraints, most of the data was explained in a more general way. The above-mentioned programs, financial instruments, and innovations, while broke-down into narrowed fields and studied separately, would help to understand how they contributed to sustaining the innovative conditions from a different perspective. Secondly, there is a lack of data available on the scholarly approved platforms written by third parties, therefore most of the information was taken from the official reports of the organizations themselves. The positive effect of those programs, therefore, could be slightly biased. It is highly recommended to make further deeper research on this topic and study it in more narrowed criteria, such as the government policies to ensure innovative competitiveness among SMEs. Additionally, the case study of Central Asian countries would also add additional value to future research, as there is a deficit of information on the web on this part of the world. While obtaining real statistics, it is believed that this kind of article would benefit not only to readers but also to the government authorities that lack international expertise.

From what has been discussed above in the article, it should be drawn a conclusion that providing small and medium-sized enterprises with an innovative environment and forcing its innovative potential can only be achieved from a multi-sided approach. For the sake of simplicity and consistency within the paper, the work was divided into two sections, where first ones analyzed the experience of developed countries, and developing ones' in the second section. The argument was proven by mentioning the importance of financial platforms for funding, such as Multilateral Trading Platform, discussing the specific country like Germany and its policies to obtain the most favorable conditions for 
their SMEs. The digitalization of SMEs is also an important element in having up-to-date businesses that can integrate technological innovations into their work. In terms of less developed countries, such as African and some Asian states, it was shown that special international organizations are offered for them to acquire the recent updates and world practices to achieve the highest level of development. It should be stated that for Kazakhstan to reach the goal of having the innovative environment to their SMEs, they should not concern only one practice, the similar idea is supported by OECD [6]. Only in the case when multiple policies and actions are realized simultaneously, a state can achieve such a result as such countries like Germany do.

\title{
LIST OF LITERATURE
}

1 Elisa O., Suomen Y. What percentage of your company's last year's growth is due to digitalization? 2018. [online]. In Statista. Available from: https://www.statista.com/statistics/881830/digitalizationcontribution-to-sme-growth-in-finland/ (accessed 24.12.2019).

2 Elkin M. Supporting small and medium-sized enterprises to grow and create better jobs. - 2018. [online]. Swiss Confederation International Labor Office. Available from: https:/www.ilo.org/wcmsp5/groups/public/--ed_emp/---emp_ent/documents/publication/wcms_607488.pdf/(accessed 26.12.2019).

3 Enhancing the Contributions of SMEs in a Global and Digitalised Economy. [online]. OECD.2017. Available from: https://www.oecd.org/mcm/documents/C-MIN-2017-8-EN.pdf (accessed 10.10.2019).

4 Herr H., Nettekoven Z. (2017). The Role of Small and Medium-sized Enterprises in Development: What Can be Learned from the German Experience? [online]. Friedrich-Ebert-Stiftung. Available from: http://library. fes.de/pdf-files/iez/14056.pdf (accessed 11.10.2019).

5 Shenzhen Stock Exchange. SME Board's 15th Birthday. 2019. [online]. Available from: http://www. szse.cn/English/about/news/szse/t20190528_567473.html (accessed 29.08.2019).

$6 \mathrm{SME}$ and Entrepreneurship Characteristics and Performance in Kazakhstan. / SME and Entrepreneurship Policy in Kazakhstan 2018. [online]. OECD Publishing, Paris. Available from: https://doi. org/10.1787/9789264301450-6-en (accessed 10.10.2019).

7 Supporting small and medium industry clusters | UNIDO. (2019). Retrieved 29 August 2019, from: https://www.unido.org/our-focus/advancing-economic-competitiveness/supporting-small-and-mediumindustry-clusters.

8 Zero2IPO. Distribution of Chinese IPOs based on number of IPOs from January 2018 to May 2019, by stock exchange. [online]. In Statista. Available from: https:/www.statista.com/statistics/1028112/chinanumber-distribution-of-chinese-ipos-by-stock-exchange-each-month/ (accessed 24.12.2019).

Б.М. БАЯДИЛОВА, ${ }^{1}$ докторант.

А.А. АМАНБАЕВА,

$\mathrm{PhD}$.

А.С. КОЙЧУБАЕВ,

$\mathrm{PhD}$, қауымдастырылған профессор м.а.

Қазақ инновациялық

гуманитарлық-заң университеті. ${ }^{1}$

Семей қаласының Шәкәрім атындағы мемлекеттік университеті ${ }^{2}$

\section{ШАҒЫН ЖӘНЕ ОРТА КӘСІПКЕРЛІКТІ ДАМЫТУ ҮШІН ИННОВАЦИЯЛЫҚ ОРТАНЫ ҚАЛЫПТАСТЫРУДЫН ШЕТЕЛДІК ТӘЖІРИБЕСІ}

\begin{abstract}
Андатпа
Бұл мақала шағын және орта бизнес арасында инновациялық ортаны игеруде және Қазақстанда инновациялық әлеуетті құруда түрлі халықаралық сараптамалардың тиімділігін қарастырады. Шағын және орта бизнес секторы әлемнің әрбір экономикасының ажырамас бөлігі болып саналады, бұған жұмыс орындарын ұлғайту және ЖІӨ өсуі сияқты көптеген түсініктеме бар, сондықтан осы нарықтың тиімділігі мен өнімділігін арттыру үшін қолданылатын көптеген түрлі тәжірибелер бар. Сонымен қатар, осы зерттеуде жалпы шағын
\end{abstract}


және орта бизнестің іскерлік ортасын жақсартудың мүмкін болатын шаралары ғана емес, шағын және орта бизнес субъектілерін тікелей ынталандыруға бағытталған нақты шаралар да келтіріледі. Кейбір дамыған елдер IPO-ға шағын және орта бизнесті тарту сияқты жаңа инновациялық қаржы платформаларын енгізсе, дамушы елдерде шағын және орта бизнес үшін әлемдік деңгейдегі арнайы оқу бағдарламаларын ұсынатын халықаралық ұйымдармен ынтымақтастықтасу арқылы кедейлікпен күресу мүмкіндігі бар. Бұдан басқа, табысты интеграцияланған технологиялар компанияларының мысалына негізделе отырып, шағын және орта кәсіпорындардың операциялық процестерін цифрлаудың маңыздылығы атап өтіледі. Әр түрлі практиктер айтарлықтай жеке үлес қоса алатын фактіні ескере отырып, мақала инновациялық ортаны құру саясаты мемлекеттік қолдауға ғана емес, сондай-ақ мемлекет көмегімен жаңа инновациялық жобаларды енгізуге де шоғырлана отырып, бір мезгілде жүзеге асырылатын әртүрлі қызмет түрлерін қамтитын көп жақты болуы тиіс деп бекітеді. Осы мақалада алынған қорытындылар Қазақстан Республикасында және Орталық Азия елдерінде шағын және орта бизнесті дамытуда берілген әдістемелер мен тәжірибелерді қабылдау үшін негіз болады.

Тірек сөздер: бизнесті қолдау, инновациялар, халықаралық жобалар, цифрландыру, бизнесті әртараптандыру, инновациялық әлеует, шағын және орта бизнес, тиімділік.

Б.М. БАЯДИЛОВА, ${ }^{1}$ докторант.

А.А. АМАНБАЕВА, ${ }^{1}$

$\mathrm{PhD}$.

А.С. КОЙЧУБАЕВ, ${ }^{2}$

$\mathrm{PhD}$, и.о. ассоциированного профессора. Казахский гуманитарно-юридический инновационный университет. ${ }^{1}$ Государственный университет им. Шакарима города Семей ${ }^{2}$

\title{
ЗАРУБЕЖНЫЙ ОПЫТ ФОРМИРОВАНИЯ ИННОВАЦИОННОЙ СРЕДЫ ДЛЯ РАЗВИТИЯ МАЛОГО И СРЕДНЕГО ПРЕДПРИНИМАТЕЛЬСТВА
}

\begin{abstract}
Аннотация
В статье рассматривается эффективность различных международных практик в освоении инновационной среды малого и среднего бизнеса и создании инновационного потенциала в Казахстане. Сектор малого и среднего бизнеса считается неотъемлемой частью каждой экономики мира, на это имеется много объяснений, такие, как увеличение рабочих мест и рост ВВП, поэтому существует огромное количество различных практик, применяемых для повышения эффективности и продуктивности этого рынка. В данном исследовании приводятся не только возможные меры улучшения деловой среды малого и среднего бизнеса в целом, но и конкретные меры, направленные на прямое стимулирование субъектов малого и среднего бизнеса. В то время как некоторые развитые страны внедряют новейшие инновационные финансовые платформы, такие, как привлечение малого и среднего бизнеса к IPO, для развивающихся стран существует возможность борьбы с бедностью в сотрудничестве с международными организациями, которые предоставляют специальные учебные программы мирового уровня для малого и среднего бизнеса. Кроме того, подчеркивается важность оцифровки операционных процессов малых и средних предприятий, основываясь на примере компаний, успешно интегрировавших технологии. Даже учитывая тот факт, что различные практики могут внести значительный индивидуальный вклад, статья утверждает, что политика создания инновационной среды должна быть многосторонней, включающей различные виды деятельности, осуществляемые одновременно, сосредоточиваясь не только на государственной поддержке, но и на внедрении новых инновационных проектов с помощью государства. Полученные выводы дают основание для принятия данных методик и практик в развитии малого и среднего бизнеса в Республике Казахстан и странах Центральной Азии.
\end{abstract}

Ключевые слова: поддержка бизнеса, международные проекты, цифровизация, диверсификация бизнеса, инновационный потенциал, малый и средний бизнес, эффективность. 